\title{
Density, Viscosity and Water Phase Stability of 1-Butanol-Gasoline Blends
}

\author{
Zlata Mužíková, Pavel Šimáček, Milan Pospíšil, and Gustav Šebor \\ Department of Petroleum Technology and Alternative Fuels, Institute of Chemical Technology, Technicka 5, \\ 16628 Prague, Czech Republic \\ Correspondence should be addressed to Zlata Mužíková; zlata.muzikova@vscht.cz
}

Received 8 October 2013; Accepted 9 December 2013; Published 27 January 2014

Academic Editor: Xingcai Lu

Copyright (C) 2014 Zlata Mužíková et al. This is an open access article distributed under the Creative Commons Attribution License, which permits unrestricted use, distribution, and reproduction in any medium, provided the original work is properly cited.

\begin{abstract}
The aim of this work was to describe the density and viscosity and water tolerance of 1-butanol-gasoline blends. Density and viscosity of 1-butanol are higher than that for gasoline and they can affect these parameters in the final gasoline blend. Density increases linearly and viscosity exponentially with the content of 1-butanol. Water solubility in 1-butanol-gasoline blend was determined as the temperature of a phase separation. The water was separated in the solid form at negative temperature and the phase separation point was determined as the temperature of crystallization. Influence of ethanol and ethers used for gasoline blending on water phase stability of 1-butanol-gasoline blend was studied. Ethers are slightly miscible with water and they improve the phase stability. While ethanol is completely miscible water and increases the water solubility in the blends. Finally, water extractions of both alcohols from gasoline were done. In contrast to the ethanol-gasoline blends, 1-butanol remained in the hydrocarbon phase.
\end{abstract}

\section{Introduction}

Butanol exists in four isomers. Two isomers 1-butanol (nbutanol and butan-1-ol) and 2-methyl-1-propanol (isobutanol) can be easily produced from biomass via fermentation. At first, British Petroleum (BP) and DuPont conducted the research in the direction of the 1-butanol [1]. Because the octane number of isoalkanes is higher than that for n-alkanes (in general), BP and other manufactures (e.g., Gevo) switched later the production to isobutanol $[2,3]$.

Nevertheless 1-butanol could be a possible alternative to the ethanol which is currently the most useful biofuel for spark ignition engines. 1-Butanol produced from waste biomass or nonfood agricultural products is classified as the biofuel of the second generation [4]. The preferred use of 1butanol in the road transport is the production of motor fuels for spark ignition engines by mixing with conventional gasoline. The highest allowed concentration of 1-butanol (classified as other oxygenates) in the gasoline in the Czech Republic is $10 \mathrm{v} / \mathrm{v} \%$ according to actual CSN EN 228 requirements.

1-Butanol could become an option for ethanol as a motor fuel for spark ignition engine due to its possible better physical-chemical properties. Properties of conventional gasoline meeting requirements of CSN EN 228 with an octane number of 95, ethanol, and 1-butanol are compared in Table 1. 1-Butanol could affect the density and viscosity of its blends with gasoline due to their higher values compared to gasoline. Higher viscosity of 1-butanol may negatively affect engine fuel injection system at lower temperatures due to higher resistance to flow and it can also negatively influence the homogenisation of fuel with air mainly for engines with direct injection system. From this view, viscosity of 1-butanol is almost half of isobutanol viscosity at $25^{\circ} \mathrm{C}\left(4.3 \mathrm{~mm}^{2} \cdot \mathrm{s}^{-1}\right)$; see Table 1 [5]. It could be a benefit for 1-butanol. Density is associated with an amount of fuel injected into the cylinder. Higher value of density results in higher amount of injected fuel.

The lower heating value (energy density) of 1-butanol is close to that of gasoline. This could have a positive effect (decrease) on the fuel consumption comparable to ethanol [8].

The Reid vapour pressure of 1-butanol is only $2.3 \mathrm{kPa}$. In contrast to ethanol, blending of 1-butanol to gasoline reduces the vapour pressure $[8,9]$. This would help meet the fuel vapour pressure limits and would help to reduce vehicle evaporative emissions. 
TABlE 1: Properties of alcohols and automotive gasoline with octane number 95 [1, 5-7].

\begin{tabular}{|c|c|c|c|c|}
\hline Parameter & Unit & Gasoline 95 & Ethanol & 1-Butanol \\
\hline Boiling point & ${ }^{\circ} \mathrm{C}$ & $30-215$ & 78.3 & 117.7 \\
\hline Density at $15^{\circ} \mathrm{C}$ & $\mathrm{Kg} \cdot \mathrm{m}^{-3}$ & $720-775$ & 794 & 809 \\
\hline Melting point & ${ }^{\circ} \mathrm{C}$ & - & -114.4 & -88.6 \\
\hline Kinematic viscosity at $25^{\circ} \mathrm{C}$ & $\mathrm{mm}^{2} \cdot \mathrm{s}^{-1}$ & $0.4-0.8$ & 1.0 & 2.6 \\
\hline Lower heating value & $\mathrm{MJ} \cdot \mathrm{kg}^{-1}$ & 44.4 & 28.9 & 33.1 \\
\hline Research octane number RON & - & 95 & $106-130^{1}$ & $94-96^{1}$ \\
\hline Motor octane number MON & - & 85 & $89-103^{1}$ & $78^{1}$ \\
\hline Reid vapour pressure & $\mathrm{kPa}$ & $45-90$ & 17 & 2.3 \\
\hline Solubility of water at $20^{\circ} \mathrm{C}$ & $\mathrm{w} / \mathrm{w} \%$ & $\sim 0.01$ & Completely miscible & 20.1 \\
\hline Stoichiometric air/fuel ratio & - & 14.8 & 9.0 & 11.1 \\
\hline Oxygen content & $\mathrm{w} / \mathrm{w} \%$ & $\max 2.7$ & 34.7 & 21.6 \\
\hline
\end{tabular}

${ }^{1}$ Blending values.

Research octane number (RON) of 1-butanol is 96 and the value is close to RON of commercial gasoline with RON min. 95; see Table $1[1,5,6]$. Isobutanol would be more attractive RON booster due to its higher octane rating RON 113 [5, 10]. Octane number is important but not limited factor for alcohols blended to the gasoline. Two publications cited RON of butanol $113[11,12]$. The parameter was not measured in the publications. One publication did not specify the isomer of butane [11]. The second work was aimed at n-butanol and it might be an incorrect value of RON [12]. In general, RON of isobutanol is higher than 1-butanol.

Currently, ethanol is used in the EU as a blend with gasoline in the amount of 5 or $10 \mathrm{v} / \mathrm{v} \%$ or it is distributed in the form of fuel ethanol E85. Due to the polar character of alcohols and their affinity to water the water-fuel miscibility becomes very important factor for distribution of the fuel blends [8]. Alcohols are complete or limited miscible with water. In contrast the solubility of water in hydrocarbons is very small and the value of gasoline is about $100 \mathrm{mg} \cdot \mathrm{kg}^{-1}$ (measured in commercial gasolines in our laboratory). An increasing amount of alcohol in gasoline blend increases the solubility of water in the blend. Water in fuel causes, namely, the corrosion and phase separation. Corrosion damages materials used in engine. The phase separation is a big problem of ethanol-gasoline blends because the solubility of water depends on the temperature. Temperature decrease can cause distribution of ethanol-gasoline blend to two phase water-ethanol and gasoline. For this reason the ethanol blends cannot be distributed in the current gasoline supply system via pipelines. The water phase absorbs about $35 \%$ of initial ethanol content [8]. In contrast the ability of 1butanol to absorb a significant amount of water is lower [13]. Unfortunately, actually valid EN 228 does not limit the water dissolved in gasoline.

Solubility of water in 1-butanol is $20.1 \mathrm{w} / \mathrm{w} \%$ at $20^{\circ} \mathrm{C}$ [7]. Solubility of water in $9.2 \mathrm{w} / \mathrm{w} \%$ 1-butanol blend with gasoline at $15^{\circ} \mathrm{C}$ was determined as $0.33 \mathrm{w} / \mathrm{w} \%$ [14]. Solubility of water is dependent on the hydrocarbon composition of gasoline [8]. In this case, the composition was as follows: $33.8 \mathrm{v} / \mathrm{v}$ aromatics and $4.4 \mathrm{v} / \mathrm{v} \%$ olefines [14]. Other work presented water solubility data for $10 \mathrm{w} / \mathrm{w} \%$ 1-butanol in gasoline [15]. But the value cannot be reliably cited due to the inadequate axis labelling in the figure [15]. Also the hydrocarbon composition was not specified so the values cannot be compared [15].

1-Butanol is not as aggressive as the ethanol with regard to the engine construction materials, sealants, and plastics. Gasoline with $20 \% \mathrm{v} / \mathrm{v}$ of 1-butanol has similar properties to the hydrocarbons in terms of swelling of elastomers [1].

The aim of this work was to describe the properties of 1butanol-gasoline blends that are important for the petroleum industry. Apparently, very little information about 1-butanolgasoline properties are available. Our experiment is focused on density and viscosity and phase stability with water. In experiments 1-butanol was combined with other oxygenates actually sold on the market methyl-tert.butyl ether (MTBE), ethyl-tert.butyl ether (ETBE), and ethanol. Oxygenates can be blended to the gasoline according to the CSN EN 228. The highest allowed contents are for 1-butanol $10 \mathrm{v} / \mathrm{v} \%$, for ethers $15 \mathrm{v} / \mathrm{v} \%$, and for ethanol $5 \mathrm{v} / \mathrm{v} \%$. Simultaneously content of all oxygenates in gasoline must meet the oxygen content of $2.7 \mathrm{w} / \mathrm{w} \%$. In the European Union in EN 228 content of oxygenates increased $10 \mathrm{v} / \mathrm{v} \%$ of ethanol, $22 \mathrm{v} / \mathrm{v} \%$ of ethers, $15 \mathrm{v} / \mathrm{v} \%$ by 1-butanol, and up to $3.7 \mathrm{w} / \mathrm{w} \%$ of oxygen. Similar increase is expected in the Czech Republic.

\section{Experimental Section}

2.1. Materials. 1-Butanol-gasoline blends were prepared from 1-butanol (p.a., 99\%, LachNer, s.r.o., Czech Republic) and gasoline without oxygenates and additives (from refinery Ceska rafinerska, a.s, Czech Republic). The composition of gasoline was $11.5 \mathrm{v} / \mathrm{v} \%$ of olefines and $35.7 \mathrm{v} / \mathrm{v} \%$ aromatics. The sulphur content was $10 \mathrm{mg} \cdot \mathrm{kg}^{-1}$, the density was $751.3 \mathrm{~kg} \cdot \mathrm{m}^{-3}$, and the octane number 94.1. Distillation characteristics: percentage evaporated at $70 / 100 / 150^{\circ} \mathrm{C}$ was $10 / 42 / 88 \mathrm{v} / \mathrm{v} \%$, final boiling point $189^{\circ} \mathrm{C}$, and the rest $1 \mathrm{~mL}$. It is a typical gasoline distributed in the Czech Republic. Parameters of gasoline were obtained from the refinery; they complied with the requirements of the national standard EN 228 besides research octane number that was lower than 95 due to the lack of oxygenates. All blends with gasoline 
were prepared by volume at the laboratory temperature $20^{\circ} \mathrm{C}$. Other chemicals used in the blends were ethanol (absolute, Merck, a.s.), MTBE (98.0 w/w\%, Ceska rafinerska, a.s., Czech Republic), ETBE (97.6 w/w\%, Ceska rafinerska, a.s., Czech Republic), and distilled water (ICT Prague).

2.2. Density and Viscosity Measurements. Density at $15^{\circ} \mathrm{C}$ and viscosity at $40^{\circ} \mathrm{C}$ were determined according to the ASTM D7042-04 on the automatic instrument Stabinger (Anton Paar). Repeatability is $0.3 \mathrm{~kg} \cdot \mathrm{m}^{-3}$ and reproducibility is $1.5 \mathrm{~kg} \cdot \mathrm{m}^{-3}$ for density according to the ASTM D7042. Repeatability is $0.10 \%$ and reproducibility is $0.58 \%$ for viscosity according to the ASTM D7042.

2.3. Water Measurements. Water was added to the blends and its content was determined with automatic Karl-Fischer coulometric titration (Diram, s.r.o., Czech Republic) according to ASTM D6304-03. Repeatability and reproducibility: the difference between two results exceeds the following values in one case in twenty: $0.0381 \cdot x^{0.6}(\mathrm{w} / \mathrm{w} \%)$ for the repeatability and $0.4243 \cdot x^{0.6}(\mathrm{w} / \mathrm{w} \%)$ for the reproducibility, where $x$ is the mean of duplicate measurements.

2.4. Phase Stability Measurements. Phase stability of the blends was experimentally done as water phase separation according to ASTM D6422-99. The sample was cooled down according to the procedure and every $2^{\circ} \mathrm{C}$ it was controlled to identify haze or phase separation occurrence. The precision was not developed in the standard. Repeatability was determined in our laboratory test from ten measurements and the value is $4^{\circ} \mathrm{C}$.

2.5. Extraction Measurements. No standardized measurements for alcohol extraction from gasoline exist. Extraction of 1-butanol from gasoline blend to water phase was done with water in the amount $0.5,1.0$, and $1.5 \mathrm{v} / \mathrm{v} \%$ added to $100 \mathrm{~mL}$ of the 1-butanol-gasoline blend. The extractions were done in the $150 \mathrm{~mL}$ volume separation funnel. The extraction time was chosen as $10 \mathrm{~min}$ based on the comparison of the amount of 1-butanol extracted between 5 and $60 \mathrm{~min}$. It was found that in the first 10 minutes more than $90 \%$ of 1-butanol is extracted from water. The content of 1-butanol was determined in the gasoline phase by GC-FID (PDMS column) in 1 hour after extraction when no visible foam or haze was detected. Identification of 1-butanol was done using retention time. Quantification was done using internal calibration with 1propanol in the concentration of $5 \mathrm{w} / \mathrm{w} \%$. Concentration range used for 1-butanol $0.5-15.0 \mathrm{w} / \mathrm{w} \%$ were determined using three standard solutions with $0.5-15.0 \mathrm{w} / \mathrm{w} \%$ of $1-$ butanol and with the internal standard. Extraction results are expressed as the difference between content of 1-butanol before and after extraction relative to the initial 1-butanol content in \% (rel. \%). Experimental uncertainty for the concentration of the extraction process was determined from ten measurements to the value $0.5 \mathrm{w} / \mathrm{w} \%$ of alcohol content in the blend.
TABle 2: Density at $15^{\circ} \mathrm{C}$ and kinematic viscosity at $40^{\circ} \mathrm{C}$ of $1-$ butanol-gasoline blends.

\begin{tabular}{lcc}
\hline $1-$ Butanol $(\mathrm{v} / \mathrm{v} \%)$ & Density $\left(\mathrm{kg} \cdot \mathrm{m}^{-3}\right)$ & Viscosity $\left(\mathrm{mm}^{2} \cdot \mathrm{s}^{-1}\right)$ \\
\hline 0 & 751.3 & 0.3873 \\
5 & 753.2 & 0.4235 \\
10 & 757.9 & 0.4712 \\
20 & 762.8 & 0.5769 \\
30 & 769.1 & 0.7583 \\
40 & 774.7 & 1.0039 \\
50 & 782.3 & 1.3308 \\
60 & 788.9 & 1.7212 \\
70 & 795.1 & 2.1985 \\
80 & 800.8 & 2.7436 \\
90 & 806.6 & 3.4132 \\
100 & 814.1 & 4.1482 \\
\hline
\end{tabular}

\section{Results and Discussion}

3.1. Density and Kinematic Viscosity. Density at $15^{\circ} \mathrm{C}$ and viscosity at $40^{\circ} \mathrm{C}$ were determined for the 1-butanol-gasoline blends. Viscosity of gasoline is not a standard parameter in the EN 228 and there is no limit for the parameter. Measurement of viscosity at $40^{\circ} \mathrm{C}$ which is a standard measured parameter of the diesel fuel was chosen for the viscosity comparison of gasoline blends. Limits for diesel fuel according to EN 590 are $2.0-4.5 \mathrm{~mm}^{2} \cdot \mathrm{s}^{-1}$, but the values of the fuels cannot be compared directly. Densities at $15^{\circ} \mathrm{C}$ of gasoline were $751.3 \mathrm{~kg} \cdot \mathrm{m}^{-3}$ and $814.1 \mathrm{~kg} \cdot \mathrm{m}^{-3}$ for 1 -butanol. Kinematic viscosities at $40^{\circ} \mathrm{C}$ of gasoline were $0.3873 \mathrm{~mm} \cdot \mathrm{s}^{-1}$ and $4.1482 \mathrm{~mm}^{2} \cdot \mathrm{s}^{-1}$ for 1-butanol. Density and viscosity of 1butanol are higher compared to gasoline. Experimental data are in Table 2. Density of 1-butanol-gasoline blends varied linearly according to (1) and it increased with the 1-butanol content. Viscosity varied exponentially according to (2). The equations may vary for different gasoline composition.

Consider

$$
\begin{aligned}
& \rho=0.6288 * c+750.7, \\
& \nu=0.3743 * e^{(0.0247 * c)},
\end{aligned}
$$

where $\rho$ is density at $15^{\circ} \mathrm{C}\left(\mathrm{kg} \cdot \mathrm{m}^{-3}\right), v$ is the kinematic viscosity at $40^{\circ} \mathrm{C}\left(\mathrm{mm}^{2} \cdot \mathrm{s}^{-1}\right)$ and $c$ is 1-butanol content in gasoline (v/v\%). Correlation coefficients $R^{2}$ is 0.999 for density and 0.998 for viscosity.

In Table 2, it can be seen that blends of 1-butanol up to $40 \mathrm{v} / \mathrm{v} \%$ meet density requirements according to the EN 228 $\left(720.0-775.0 \mathrm{~kg} \cdot \mathrm{m}^{-3}\right)$. Viscosity for the same content of 1butanol is $1.0039 \mathrm{~mm}^{2} \cdot \mathrm{s}^{-1}$. The value approaches the limit for the viscosity of the diesel fuel.

3.2. Water Phase Stability. Hydrocarbons in gasoline are very slightly miscible with water in contrast to alcohols. The solubility of water in petroleum gasoline was measured and it is about $100 \mathrm{mg} \cdot \mathrm{kg}^{-1}$. Ethanol is completely miscible with water, but the solubility of water in 1-butanol is $20.1 \mathrm{w} / \mathrm{w} \%$ 


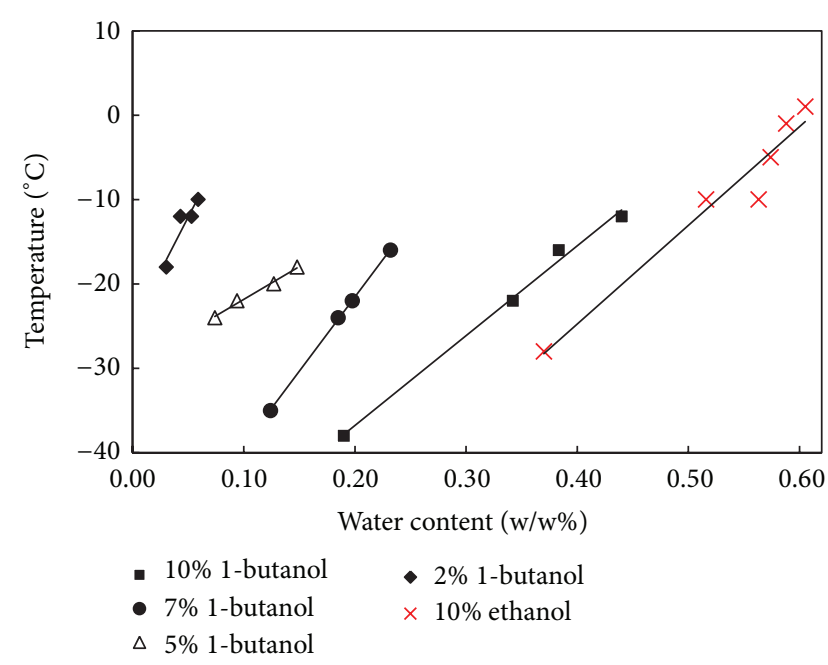

FIGURE 1: Solubility of water in 1-butanol-gasoline blends expressed as the temperature of crystallization. The temperature of the haze point of the ethanol-gasoline blends is added for the comparison. Alcohol content in blends is expressed in volume \%. Linear regression equations are in Table 3.

at $20^{\circ} \mathrm{C}$ [7]. Because of the limited miscibility of water and hydrocarbons (gasoline) and water and 1-butanol, the mixture of 1-butanol, gasoline, and water is also limited miscible. The ternary system consists of the two limited miscible couples. In contrast, the ternary system for ethanol-gasoline-water consists only of the one limited miscible couple (gasolinewater). In general, the mutual miscibility in the ternary system is next to the composition related very closely to the temperature. And it may be the same problem with phase separation as with ethanol-gasoline blends.

Determination of solubility of water in the 1-butanolgasoline blend was done according to the ASTM 6422 as the phase separation. No similar procedure exists in EN standards. Formation of a haze, at the first, and then formation of two immiscible phases at the next cooling down are typical manifestations of phase separation for ethanol-gasoline blends. Both phases are in liquid form. For the 1-butanol-gasoline blends, the water created crystals at temperatures less than $0^{\circ} \mathrm{C}$ were separated in the solid phase. The temperature of the phase separation with crystal formation was called crystallization temperature.

The water solubility determined for 1-butanol-gasoline blends are in Figure 1. In general, solubility of water in dependence of the temperature fitted the linear equation. Parameters of the linear equations are presented in Table 3. Data for the ethanol-gasoline blend are determined for both alcohols to compare them (see Figure 1). The highest concentration of $10 \mathrm{v} / \mathrm{v} \%$ of 1-butanol was prepared in accordance with the highest limit according to EN 228. The solubility of water in both alcohol-gasoline blends at the $10 \mathrm{v} / \mathrm{v} \%$ is very similar. The difference between them is about $0.05 \mathrm{w} / \mathrm{w} \%$ in favour of ethanol. It can be seen in Figure 1 that the slope of the 5\% 1-butanol line differs from surrounding lines for blends with 2 and 7\% 1-butanol. There is no satisfactory explanation.

Experimental data of all phase separation measurements are in Table 4.
TABLE 3: Parameters $A$ and $B$ of the linear equation $y=A x+B$ in Figures 1, 3, and 4 and the correlation coefficient $R^{2}$ for each fit. $y$ is the temperature of haze point/phase separation/crystallization in ${ }^{\circ} \mathrm{C}$ and $x$ is water content in $\mathrm{w} / \mathrm{w} \%$.

\begin{tabular}{lccc}
\hline Sample & $A$ & $B$ & $R^{2}$ \\
\hline 2\% 1-butanol & 257.1 & 24.9 & 0.87 \\
5\% 1-butanol & 78.7 & 29.6 & 0.99 \\
7\% 1-butanol & 176.1 & 56.8 & 0.99 \\
10\% 1-butanol & 106.5 & 58.1 & 0.99 \\
10\% ethanol & 117.1 & 71.6 & 0.95 \\
5\% 1-butanol + 5\% ethanol & 104.0 & 64.8 & 0.93 \\
5\% 1-butanol + 10\% ethanol & 60.1 & 57.5 & 0.99 \\
10\% 1-butanol + 5\% ethanol & 127.0 & 135.3 & 0.98 \\
10\% 1-butanol + 10\% ethanol & 42.8 & 86.8 & 0.91 \\
5\% 1-butanol + 10\% MTBE & 259.0 & 75.4 & 0.88 \\
5\% 1-butanol + 10\% ETBE & 222.4 & 62.3 & 0.95 \\
10\% 1-butanol + 5\% MTBE & 148.5 & 86.8 & 0.96 \\
10\% 1-butanol + 10\% MTBE & 159.2 & 96.8 & 0.87 \\
\hline
\end{tabular}

The water solubility in dependence on the 1-butanol content was created for the temperature of $-20^{\circ} \mathrm{C}$ (see Figure 2) from the data in Figure 1. The dependence (Figure 2) is close to the linear fit in this range of the 1-butanol content.

Data in Table 5 were extrapolated from data in Figure 1 experimentally determined during phase separation of 1butanol-gasoline blends. Data in Table 5 represent the highest content of water that remains dissolved in 1-butanol-gasoline, while the temperature is higher than $-30^{\circ} \mathrm{C}$. The temperature $-30^{\circ} \mathrm{C}$ represents the usual lowest limit of temperature in the Middle of Europe.

It was found that water was separated from the 1-butanolgasoline blend in the solid form at temperatures less than $0^{\circ} \mathrm{C}$. This means that 1-butanol remained in the gasoline phase because the melting points of both gasoline and 1-butanol are very low (see Table 1). This is a big benefit as opposed to ethanol-gasoline blends. Experiments with extractions of 1butanol to the water were done at ambient temperature $20^{\circ} \mathrm{C}$. The extractions of ethanol from gasoline blends were done for both alcohols for the comparison. Water was added to the gasoline blend in the amount of $0.5 ; 1.0$ and $1.5 \mathrm{v} / \mathrm{v} \%$. Results are presented in Table 6. The amount of extracted 1butanol is dependent on the water and 1-butanol content. The highest decrease of 1-butanol in gasoline phase 10 rel. \% was determined for the blend by $5 \mathrm{v} / \mathrm{v} \%$ of 1-butanol in gasoline and $1.5 \mathrm{v} / \mathrm{v} \%$ of water. It must be noted that some water added to the 1-butanol-gasoline is dissolved in the mixture. The amount of dissolved water increases with alcohol content in the blend. This is a reason for the lower content of 1-butanol extracted from 10\% 1-butanol-gasoline blend in opposite to the 5\% 1-butanol-gasoline blend. Comparing to 1-butanol, ethanol is extracted into the water in higher amounts up to 40 rel. \%.

3.2.1. Presence of Other Oxygenates. In previous experiments it was found that 1-butanol-gasoline mixtures are characterised by the formation of solid crystals of water when the 
TABLE 4: Temperature of the phase separation and the water content in samples presented in Figures 1, 3, and 4.

\begin{tabular}{|c|c|c|c|c|c|}
\hline Sample & Water (w/w\%) & $t\left({ }^{\circ} \mathrm{C}\right)$ & Sample & Water (w/w\%) & $t\left({ }^{\circ} \mathrm{C}\right)$ \\
\hline 2\% 1-butanol & 0.0304 & -18 & $5 \%$ 1-butanol + 10\% ethanol & 0.9670 & 2 \\
\hline 2\% 1-butanol & 0.0430 & -12 & $5 \%$ 1-butanol $+10 \%$ ethanol & 1.1670 & 12 \\
\hline 2\% 1-butanol & 0.0530 & -12 & $10 \%$ 1-butanol $+5 \%$ ethanol & 1.1113 & 6 \\
\hline 2\% 1-butanol & 0.0590 & -10 & $10 \%$ 1-butanol $+5 \%$ ethanol & 1.1072 & 4 \\
\hline 5\% 1-butanol & 0.0740 & -24 & $10 \%$ 1-butanol $+5 \%$ ethanol & 1.0442 & -2 \\
\hline 5\% 1-butanol & 0.0940 & -22 & $10 \%$ 1-butanol + 5\% ethanol & 1.1312 & 8 \\
\hline 5\% 1-butanol & 0.1270 & -20 & $10 \%$ 1-butanol $+5 \%$ ethanol & 1.1691 & 14 \\
\hline 5\% 1-butanol & 0.1480 & -18 & $10 \%$ 1-butanol $+10 \%$ ethanol & 1.7299 & -16 \\
\hline 7\% 1-butanol & 0.1240 & -35 & $10 \%$ 1-butanol $+10 \%$ ethanol & 1.8051 & -10 \\
\hline 7\% 1-butanol & 0.1850 & -24 & $10 \%$ 1-butanol $+10 \%$ ethanol & 1.9372 & -2 \\
\hline 7\% 1-butanol & 0.2320 & -16 & $10 \%$ 1-butanol $+10 \%$ ethanol & 1.5207 & -20 \\
\hline 7\% 1-butanol & 0.1976 & -22 & $5 \%$ 1-butanol + 10\% MTBE & 0.2170 & -18 \\
\hline $10 \%$ 1-butanol & 0.3420 & -22 & 5\% 1-butanol + 10\% MTBE & 0.2150 & -18 \\
\hline 10\% 1-butanol & 0.4400 & -12 & 5\% 1-butanol + 10\% MTBE & 0.1930 & -30 \\
\hline $10 \%$ 1-butanol & 0.3834 & -16 & $5 \%$ 1-butanol + 10\% MTBE & 0.1500 & -35 \\
\hline $10 \%$ 1-butanol & 0.1900 & -38 & $5 \%$ 1-butanol + 10\% ETBE & 0.1880 & -20 \\
\hline $10 \%$ ethanol & 0.5633 & -10 & $5 \%$ 1-butanol + 10\% ETBE & 0.1560 & -30 \\
\hline $10 \%$ ethanol & 0.3700 & -28 & $5 \%$ 1-butanol + 10\% ETBE & 0.1970 & -18 \\
\hline $10 \%$ ethanol & 0.5742 & -5 & $5 \%$ 1-Butanol + 10\% ETBE & 0.1300 & -32 \\
\hline $10 \%$ ethanol & 0.5880 & -1 & 10\% 1-butanol + 5\% MTBE & 0.4731 & -18 \\
\hline $10 \%$ ethanol & 0.6052 & 1 & 10\% 1-butanol + 5\% MTBE & 0.3935 & -26 \\
\hline $10 \%$ ethanol & 0.5161 & -10 & 10\% 1-butanol + 5\% MTBE & 0.4863 & -14 \\
\hline $5 \%$ 1-butanol $+5 \%$ ethanol & 0.5117 & -10 & 10\% 1-butanol + 5\% MTBE & 0.3600 & -35 \\
\hline $5 \%$ 1-butanol $+5 \%$ ethanol & 0.6277 & 6 & $10 \%$ 1-butanol + 10\% MTBE & 0.5485 & -12 \\
\hline $5 \%$ 1-butanol $+5 \%$ ethanol & 0.6774 & 0 & $10 \%$ 1-butanol + 10\% MTBE & 0.4326 & -28 \\
\hline $5 \%$ 1-butanol $+5 \%$ ethanol & 0.3000 & -35 & $10 \%$ 1-butanol + 10\% MTBE & 0.4585 & -18 \\
\hline $5 \%$ 1-butanol $+10 \%$ ethanol & 0.7330 & -14 & $10 \%$ 1-butanol + 10\% MTBE & 0.3900 & -38 \\
\hline
\end{tabular}

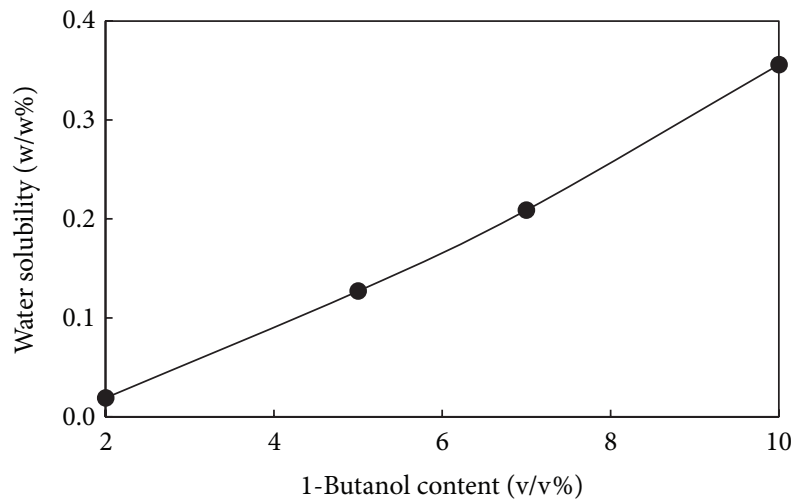

FIGURE 2: Water solubility (determined as crystallization temperature) in 1-butanol-gasoline blends with different content of 1-butanol at $-20^{\circ} \mathrm{C}$.

phase separation occurs at temperatures less than $0^{\circ} \mathrm{C}$. However, ethanol-gasoline blends form two immiscible liquid phases with ethanol distributed in the both phases. The aim of the following experiments was to determine the properties of mixtures with several oxygenates. Oxygenates can be mixed with the gasoline for the octane number meeting or they can be mixed due to the mixing of different types of
TABLE 5: The content of dissolved water in 1-butanol-gasoline blend for the temperature of crystallization lower than $-30^{\circ} \mathrm{C}$.

\begin{tabular}{|c|c|}
\hline 1-Butanol (v/v\%) & Water (w/w\%) \\
\hline 2 & 0.01 \\
\hline 5 & 0.04 \\
\hline 7 & 0.15 \\
\hline 10 & 0.28 \\
\hline
\end{tabular}

gasoline. Actually, ethanol is blended with gasoline to meet requirements of EU directives and $\mathrm{MTBE}$ and ETBE are most useful components of high-octane number gasoline (Natural 98 and higher). Base 1-butanol concentrations in gasoline were chosen to 5 and $10 \mathrm{v} / \mathrm{v} \%$ in experiments. Ethanol at concentrations of 5 and $10 \mathrm{v} / \mathrm{v} \%$ was combined with both 1butanol concentrations. See Figure 3 for results. Parameters of the linear equations are presented in Table 3.

Ethanol has high affinity to water. Its addition to the 1-butanol-gasoline phase increases the water solubility in the mixture according to the content of ethanol (Figure 3). The addition of $5 \mathrm{v} / \mathrm{v} \%$ of ethanol to $5 \mathrm{v} / \mathrm{v} \%$ of 1 -butanol increased the water solubility of about $2000 \mathrm{mg} \cdot \mathrm{kg}^{-1}$. The addition of $10 \mathrm{v} / \mathrm{v} \%$ of ethanol increased the solubility up to 
TABLE 6: Water extraction of ethanol and 1-butanol from gasoline blend.

\begin{tabular}{|c|c|c|c|}
\hline $\begin{array}{l}\text { Extracted } \\
\text { alcohol }\end{array}$ & $\begin{array}{c}\text { Alcohol in gasoline } \\
\text { before extraction } \\
(\mathrm{w} / \mathrm{w} \%)\end{array}$ & $\begin{array}{l}\text { Water added } \\
(\mathrm{v} / \mathrm{v} \%)\end{array}$ & $\begin{array}{l}\text { Alcohol content } \\
\text { decrease (rel.\%) }\end{array}$ \\
\hline \multirow{9}{*}{ Ethanol } & \multirow{3}{*}{1.7} & 0.5 & 17.6 \\
\hline & & 1.0 & 23.5 \\
\hline & & 1.5 & 41.2 \\
\hline & \multirow{3}{*}{4.8} & 0.5 & 18.8 \\
\hline & & 1.0 & 27.1 \\
\hline & & 1.5 & 41.7 \\
\hline & \multirow{3}{*}{9.2} & 0.5 & 2.2 \\
\hline & & 1.0 & 26.1 \\
\hline & & 1.5 & 37.0 \\
\hline \multirow{9}{*}{ 1-Butanol } & \multirow{3}{*}{4.1} & 0.5 & 4.9 \\
\hline & & 1.0 & 4.9 \\
\hline & & 1.5 & 7.3 \\
\hline & \multirow{3}{*}{7.1} & 0.5 & 4.2 \\
\hline & & 1.0 & 5.6 \\
\hline & & 1.5 & 9.9 \\
\hline & \multirow{3}{*}{12.2} & 0.5 & 4.9 \\
\hline & & 1.0 & 3.3 \\
\hline & & 1.5 & 6.6 \\
\hline
\end{tabular}

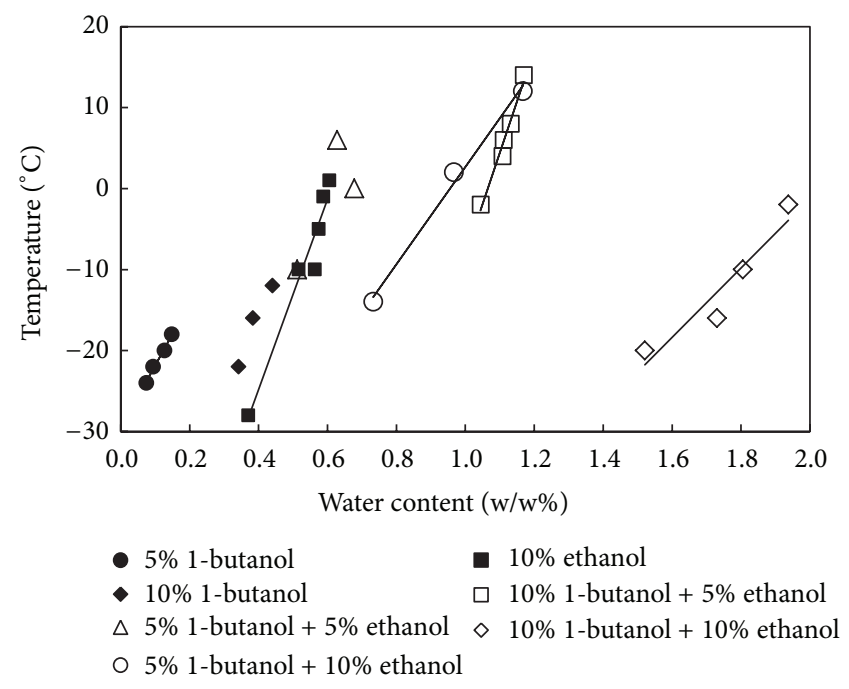

FIGURE 3: The crystallization temperature of 1-butanol-gasoline blends and the haze point temperature of ethanol- and 1-butanolethanol-gasoline blends. Linear regression equations are in Table 3.

$6000 \mathrm{mg} \cdot \mathrm{kg}^{-1}$ (see Figure 3). Ethanol is completely soluble in water and it decreases the melting point of water. For ethanol and 1-butanol mixtures water separated from gasoline phase absorbs an amount of ethanol and two liquid phases occur. During experiment both haze point and phase separation point were found. In Figure 3, there are crystallization points of 1-butanol-gasoline blends and haze points for 1-butanolethanol-gasoline and ethanol-gasoline blends.

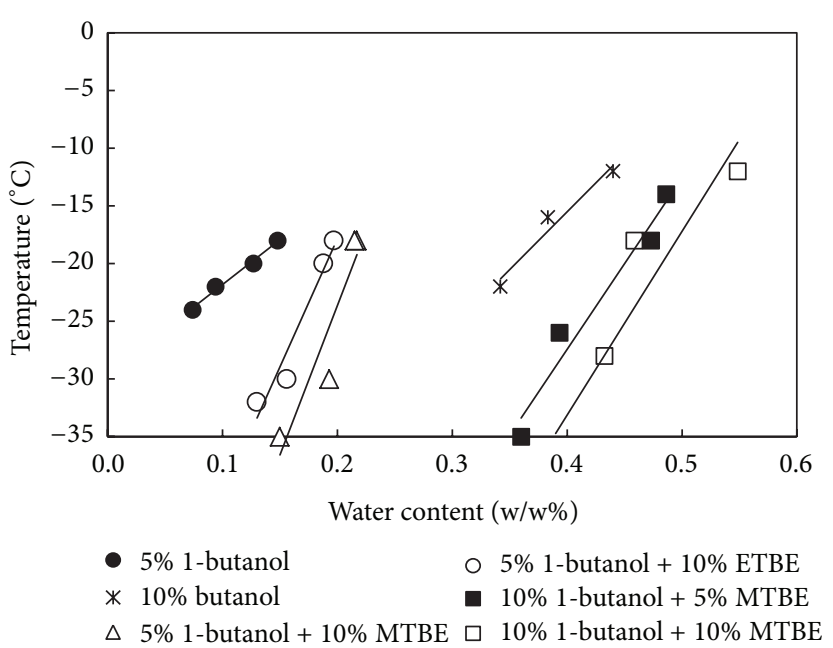

FIGURE 4: The crystallization temperature of 1-butanol-gasoline and 1-butanol-ether-gasoline blends. Linear regression equations are in Table 3.

MTBE and ETBE in a concentration of $10 \mathrm{v} / \mathrm{v} \%$ were combined with $5 \mathrm{v} / \mathrm{v} \%$ of 1-butanol and MTBE in 5 and $10 \mathrm{v} / \mathrm{v} \%$ was combined with $10 \mathrm{v} / \mathrm{v} \%$ of 1 -butanol. See Figure 4 for results. Parameters of the linear equations are presented in Table 3. The oxygen content in mixtures is in Table 7. Ethers added to the 1-butanol-gasoline blend increased the water solubility only a little compared to ethanol. Ethers are slightly soluble in water and they have properties close to hydrocarbons. Crystals of water were detected at the phase separation point at a temperature less than $0^{\circ} \mathrm{C}$ and no haze point was detected.

\section{Conclusions}

1-Butanol is one of the biofuels produced from biomass. Due to the fact that the oxygen content in 1-butanol is lower than in ethanol, 1-butanol can be added to the gasoline in higher concentrations (up to 10 vol. \%) with respect to EN 228 limit to the oxygen content in gasoline. 1-Butanol has high affinity to hydrocarbons and 1-butanol reduces the effect of alcohol extraction associated with water-induced phase separation. Moreover, 1-butanol remains in the hydrocarbon phase if the phase separation occurs at temperatures less than $0^{\circ} \mathrm{C}$. Much of the 1-butanol (about 90 rel. \%) remains in the hydrocarbon phase when phase separation occurs at temperatures higher than $0^{\circ} \mathrm{C}$. 1-Butanol is not hygroscopic and it is an important factor for the transportation of fuel in the current gasoline supply system and for the long-term storage of fuels.

Ethers MTBE and/or ETBE can be added to the gasoline for the purpose of increasing the octane number and oxygen content or they can be accidentally mixed in the fuel tank due to another type of gasoline fuelling. The presence of MTBE and ETBE slightly increases the miscibility of 1-butanolgasoline blend with water and decreases the temperature of the phase separation. Ethanol acts in the same way. It increases significantly the water solubility. 
TABLE 7: Content of total oxygen in gasoline blends.

\begin{tabular}{|c|c|c|c|c|}
\hline \multirow[b]{2}{*}{ 1-Butanol } & \multicolumn{3}{|c|}{ Oxygenates in gasoline blend $(\mathrm{v} / \mathrm{v} \%)$} & \multirow{2}{*}{ Oxygen (w/w\%) } \\
\hline & Ethanol & MTBE & ETBE & \\
\hline 10 & - & - & - & 2.3 \\
\hline 7 & - & - & - & 1.6 \\
\hline 5 & - & - & - & 1.2 \\
\hline 2 & - & - & - & 0.5 \\
\hline 5 & - & 10 & - & 2.9 \\
\hline 5 & - & - & 10 & 2.7 \\
\hline 5 & 5 & - & - & 3.0 \\
\hline 5 & 10 & - & - & 4.8 \\
\hline 10 & - & 5 & - & 3.2 \\
\hline 10 & - & 10 & - & 4.1 \\
\hline 10 & 5 & - & - & 4.1 \\
\hline 10 & 10 & - & - & 5.9 \\
\hline
\end{tabular}

1-Butanol increases density and viscosity of gasoline. No data of an influence of these higher parameters on the engine fuel system exists and it needs an additional work.

\section{Conflict of Interests}

The authors declare that there is no conflict of interests regarding the publication of this paper.

\section{Acknowledgment}

This work was performed under the Ministry of Agriculture under contract no. QH81323/2008 of the Ministry of Agriculture of the Czech Republic.

\section{References}

[1] L. Wolf, "1-Butanol as a Gasoline Blending Biocomponent," Mobile Sources Technical Review Subcommittee-Meeting, Aarlington, Tex, USA, 2007, http://www.epa.gov/oar/caaac/ mstrs/March2007/Wolf.pdf.

[2] http://www.butamax.com.

[3] http://www.gevo.com.

[4] F. A. Rainey, B. J. Hollen, A. Small, and I. Genus, Clostridium Prazmowski, Springer, New York, NY, USA, 2nd edition, 1880.

[5] C. Jin, M. Yao, H. Liu, C.-F. F. Lee, and J. Ji, "Progress in the production and application of n-butanol as a biofuel," Renewable and Sustainable Energy Reviews, vol. 15, no. 8, pp. 4080-4106, 2011.

[6] J. Serras-Pereira, P. G. Aleiferis, D. Richardson, and S. Wallace, "Characteristics of ethanol, butanol, iso-octane and gasoline sprays and combustion from a multi-hole injector in a DISI engine," SAE International Journal of Fuels and Lubricants, vol. 1, no. 1, pp. 893-909, 2009.

[7] n-Butanol, "BASF Technical Leaflet," http://www.solvents.basf .com/portal/load/fid228768/n_Butanol_e_03_08.pdf.

[8] Z. Mužíková, M. Pospíšil, and G. Šebor, "Volatility and phase stability of petrol blends with ethanol," Fuel, vol. 88, pp. 13511356, 2009.
[9] V. F. Andersen, J. E. Anderson, T. J. Wallington, S. A. Mueller, and O. J. Nielsen, "Vapor pressures of alcohol-gasoline blends," Energy and Fuels, vol. 24, no. 6, pp. 3647-3654, 2010.

[10] A. Yasar, "Effects of alcohol-gasoline blends on exhaust and noise emissions in small scaled generators," Metalurgija, vol. 49, no. 4, pp. 335-338, 2010.

[11] X. Yang, J. Yang, and T. Lin, “The effect of an SI engine using butanol-gasoline blended fuel on performance and enviroment," in International Conference on Energy and Environment Technology (ICEET '09), pp. 402-405, October 2009.

[12] J. Dernotte, C. Mounaim-Rousselle, F. Halter, and P. Seers, "Evaluation of butanol-gasoline blends in a port fuel-injection, spark-ignition engine," Oil and Gas Science and Technology, vol. 65, no. 2, pp. 345-351, 2010.

[13] C. Peng, K. C. Lewis, and F. P. Stein, "Water solubilities in blends of gasoline and oxygenates," Fluid Phase Equilibria, vol. 116, no. 1, pp. 437-444, 1996.

[14] C. Peng, K. C. Lewis, and F. P. Stein, "Water solubilities in blends of gasoline and oxygenates," Fluid Phase Equilibria, vol. 116, no. 1, pp. 437-444, 1996.

[15] T. M. Letcher, C. Heyward, S. Wootton, and B. Shuttleworth, "Ternary phase diagrams for gasoline-water-alcohol mixtures," Fuel, vol. 65, no. 7, pp. 891-894, 1986. 


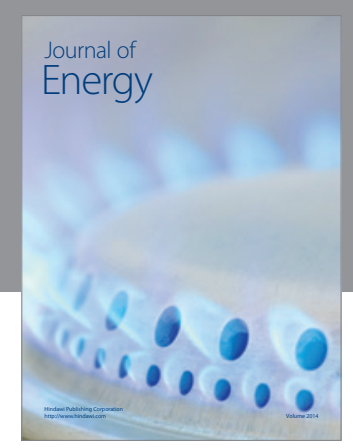

Journal of

Industrial Engineering
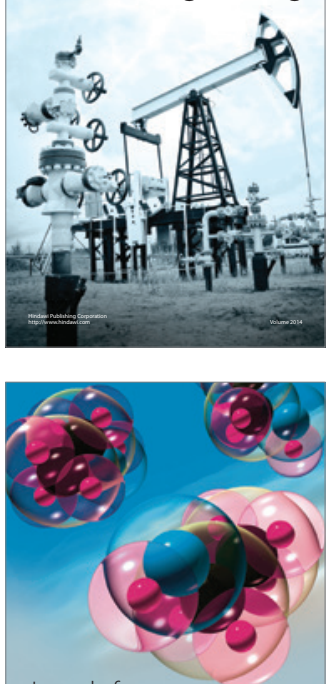

Fuels
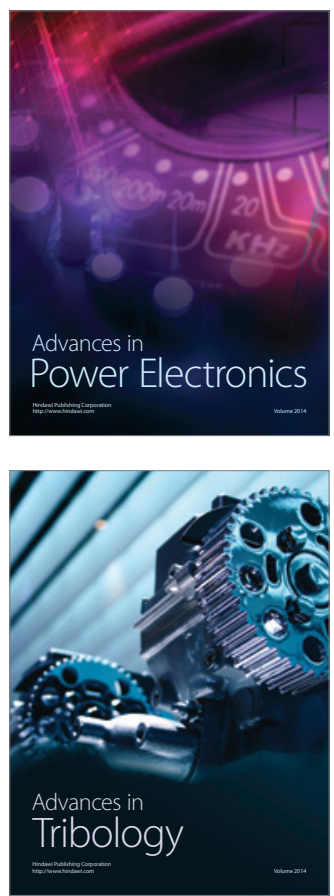

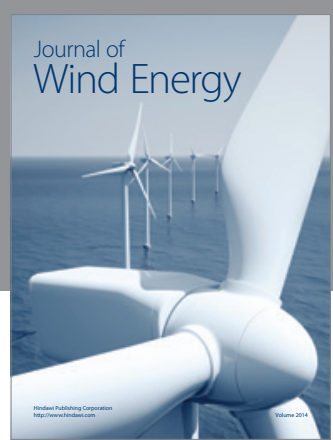

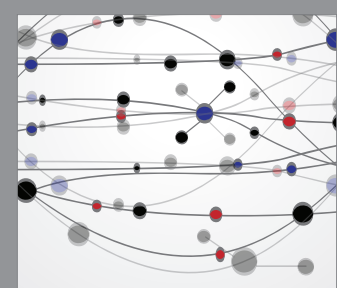

The Scientific World Journal

Submit your manuscripts at http://www.hindawi.com

Journal of

Structures
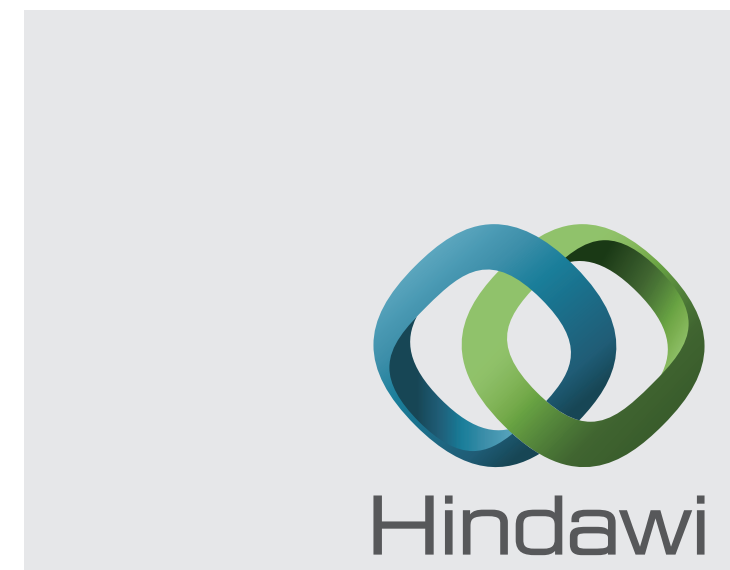

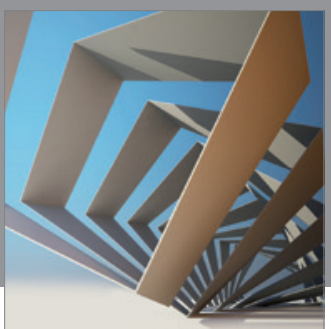

Rotating

Machinery
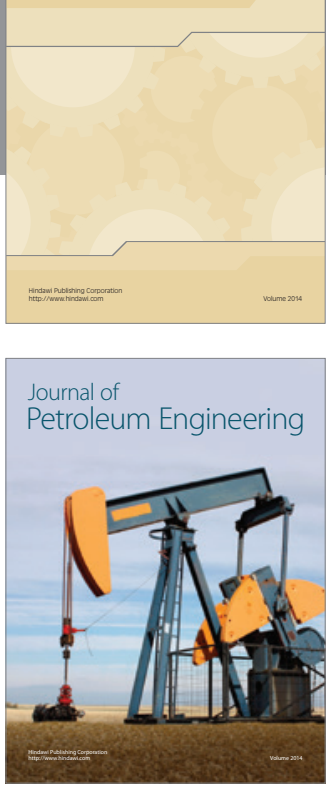

Journal of

Solar Energy
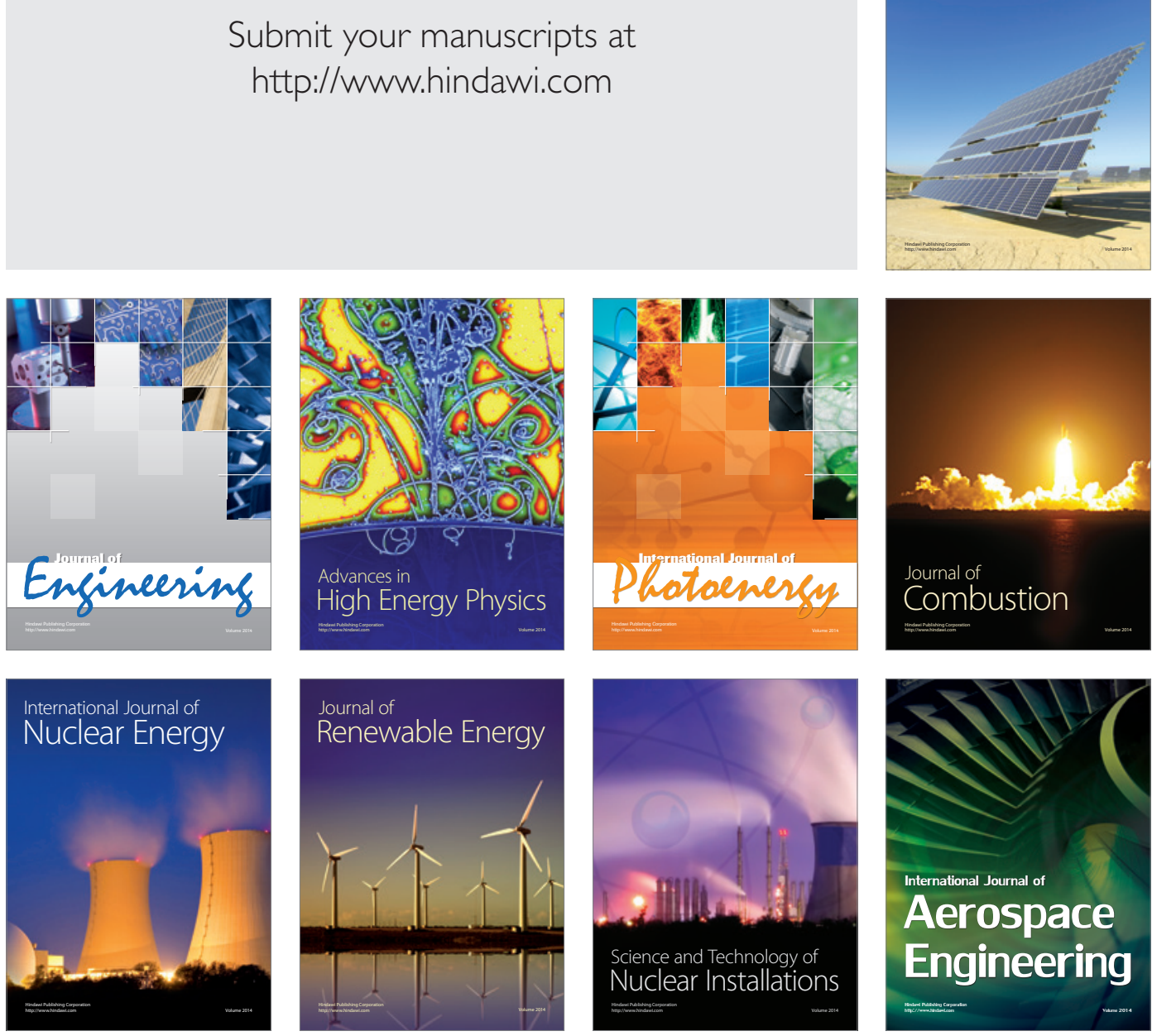